\title{
Phytoprotection
}

\section{Weed survey of spring cereals in New Brunswick}

\section{A.G. Thomas, D.J. Doohan et K.V. McCully}

Volume 75, numéro 3, 1994

URI : https://id.erudit.org/iderudit/706058ar

DOI : https://doi.org/10.7202/706058ar

Aller au sommaire du numéro

\section{Éditeur(s)}

Société de protection des plantes du Québec (SPPQ)l

ISSN

0031-9511 (imprimé)

1710-1603 (numérique)

Découvrir la revue

Citer cet article

Thomas, A., Doohan, D. \& McCully, K. (1994). Weed survey of spring cereals in New Brunswick. Phytoprotection, 75(3), 113-124.

https://doi.org/10.7202/706058ar

\section{Résumé de l'article}

En 1986 et 1987, un inventaire des mauvaises herbes a été effectué dans 187 champs de céréales de printemps au Nouveau-Brunswick. Au total, 76 espèces ont été identifiées, 40 d'entre elles étant considérées comme importantes sur le plan agronomique. Environ 50\% des espèces étaient vivaces. L'ortie royale (Galeopsis tetrahit), le chiendent (Agropyron repens), la petite oseille (Rumex acetosella), la marguerite blanche (Chrysanthemum leucanthemum), la spargoute des champs (Spergula arvensis) et la stellaire moyenne (Stellaria média) avaient les plus hautes valeurs d'abondance relative. Le chiendent et l'ortie royale avaient les plus fortes densités à 8,0 et 7,1 plantes $\mathrm{m}^{-2}$, respectivement. La densité de mauvaises herbes la plus élevée (103 plantes $\mathrm{m}^{-2}$ ) a été observée chez l'avoine (Avena sativa) cultivée à la suite de plantes fourragères. La plus faible densité a été détectée chez le blé (Triticum aestivum) suite à une culture de pomme de terre (Solanum tuberosum). La plupart des espèces abondantes étaient tolérantes au MCPA, l'herbicide le plus fréquemment utilisé. Les agriculteurs pourraient lutter plus efficacement contre les mauvaises herbes dans les céréales en choisissant un herbitolérantes au MCPA ou au 2,4-D, et a en pré-plantation ou en post-récolte ses herbes vivaces. 


\title{
Weed survey of spring cereals in New Brunswick
}

\author{
A. Gordon Thomas', Douglas J. Doohan², and Kevin V. \\ McCully
}

Received 1993-08-04; accepted 1994-10-30

During 1986 and 1987, a weed survey of 187 New Brunswick cereal fields was conducted. A total of 76 species were identified of which 40 were considered agronomically important. About $50 \%$ of the species were perennial. Hemp-nettle (Galeopsis tetrahit), quack grass (Agropyron repens), sheep sorrel (Rumex acetosella), ox-eye daisy (Chrysanthemum leucanthemum), corn spurry (Spergula arvensis), and chickweed (Stellaria media) had the highest relative abundance values. Quack grass and hemp-nettle had the highest densities at 8.0 and 7.1 plants $\mathrm{m}^{-2}$, respectively. The highest weed density (103 plants $\mathrm{m}^{-2}$ ) was found in oats (Avena sativa) grown after a forage crop. The lowest density (24 plants $\mathrm{m}^{-2}$ ) was found in wheat (Triticum aestivum) grown after potatoes (Solanum tuberosum). Most of the abundant species were tolerant to MCPA, the most commonly used herbicide. Farmers could make major improvements in cereal weed control by choosing a herbicide that would control species tolerant to MCPA or $2,4-D$, and using preplant or postharvest weed control to minimize the impact of perennial weeds.

Thomas, A.G., D.J. Doohan et K.V. McCully. 1994. Inventaire de mauvaises herbes dans les céréales de printemps au Nouveau-Brunswick. PHYTOPROTECTION 75: 113-124.

En 1986 et 1987, un inventaire des mauvaises herbes a été effectué dans 187 champs de céréales de printemps au Nouveau-Brunswick. Au total, 76 espèces ont été identifiées, 40 d'entre elles étant considérées comme importantes sur le plan agronomique. Environ $50 \%$ des espèces étaient vivaces. L'ortie royale (Galeopsis tetrahit), le chiendent (Agropyron repens), la petite oseille (Rumex acetosella), la marguerite blanche (Chrysanthemum leucanthemum), la spargoute des champs (Spergula arvensis) et la stellaire moyenne (Stellaria media) avaient les plus hautes valeurs d'abondance relative. Le chiendent et l'ortie royale avaient les plus fortes densités à 8,0 et 7,1 plantes $\mathrm{m}^{-2}$, respectivement. La densité de mauvaises herbes la plus élevée (103 plantes $\mathrm{m}^{-2}$ ) a été observée chez l'avoine (Avena sativa) cultivée à la suite de plantes fourragères. La plus faible densité a été détectée chez le blé (Triticum aestivum) suite à une culture de pomme de terre (Solanum tuberosum). La plupart des espèces abondantes étaient tolérantes au MCPA, I'herbicide le plus fréquemment utilisé. Les agriculteurs pourraient lutter plus efficacement contre les mauvaises herbes dans

1. Agriculture and Agri-Food Canada, Saskatoon Research Centre, 107 Science Place, Saskatoon, Saskatchewan, Canada S7N 0X2

2. Plant Industry Branch, Nova Scotia Department of Agriculture and Marketing, P.O. Box 550 , Truro, Nova Scotia, Canada B2N 5 E3

3. Plant Industry Branch, Department of Agriculture and Rural Development, P.O. Box 6000 , Fredericton, New Brunswick, Canada E3B 5H1 
les céréales en choisissant un herbicide qui pourrait réprimer les espèces tolérantes au MCPA ou au 2,4-D, et aussi en utilisant des méthodes de lutte en pré-plantation ou en post-récolte qui minimiseraient l'effet des mauvaises herbes vivaces.

\section{INTRODUCTION}

The survey of New Brunswick spring cereals is part of a program of the Research Branch of Agriculture and Agri-Food Canada to document relative abundance and geographic distribution of weedy species across Canada. In addition, it will provide baseline information for monitoring changes in weed populations through time. Surveys provide weed biologists and ecologists with quantitative information on weed communities that is used in the development of integrated weed management strategies, and weed scientists and extension specialists with information for weed control (herbicide) recommendations. To date, accounts of the weed flora in the provinces of Saskatchewan (Dale and Thomas 1987; Thomas 1985), Manitoba (Goodwin et al. 1986; Thomas 1991; Thomas and Dale 1991; Thomas and Donaghy 1991), Quebec (Doyon and Bouchard 1981; Doyon et al. 1982; Lemieux et al. 1988), Prince Edward Island (Thomas and Ivany 1990), and Nova Scotia (McCully et al. 1991) have been published.

Botanical lists of weedy taxa occurring in New Brunswick have been prepared by Fletcher (1897), by Groh and Frankton (1949), and by Bassett (1953); however, a quantitative assessrnent of the weed flora of New Brunswick spring cereal crops was lacking. This gap in knowledge led to the initiation of a 3-yr survey project beginning in 1985. Specific concerns were raised about the annual grassy weed, wild oats (Avena fatua L.), which was perceived to be increasing in northwestern $\mathrm{New}$ Brunswick. Wild oats is one of the most abundant and troublesome weeds of annual crops of western Canada (Sharma and Vanden Born 1978) and its presence in New Brunswick cereal fields posed a potentially serious threat. Information on the relative importance of this species in relation to other weeds in cereal crops was needed to help direct research and extension efforts. A preliminary survey was conducted during 1985 to evaluate methods and to gain support for a provincial survey conducted during 1986 and 1987. Only data from the last $2 \mathrm{yr}$ will be presented in this paper.

\section{MATERIALS AND METHODS}

\section{Description of the area}

The province of New Brunswick comprises an area of $73400 \mathrm{~km}^{2}$ located between $44^{\circ} 35^{\prime}$ and $48^{\circ} 05^{\prime}$ west longitude in eastern Canada. The surface topography is generally low and level along the east coast on the Gulf of St. Lawrence, rising to a highland region in the northwest with the highest point being $820 \mathrm{~m}$. The highlands are too rugged for farming except along the valleys of the St. John River, the largest river in the province, and the Kennebacasis River. Farming also occurs along the rivers flowing across the lowlands on the east coast. Along the St. John River Valley, the mean temperatures for January and July are approximately $-11^{\circ} \mathrm{C}$ and $18^{\circ} \mathrm{C}$, respectively, which is similar to the mean temperatures of $-10^{\circ} \mathrm{C}$ and $19^{\circ} \mathrm{C}$ along the east coast. These areas receive approximately $750 \mathrm{~mm}$ of precipitation annually (Van Groenewoud 1984).

Soils that are used for grain production in New Brunswick (Podzolic and Brunisolic orders) range from sandy to clay loam surface textures with very compacted subsurface horizons. Soils are derived primarily from glacial, marine or alluvial deposits. Surface horizons vary in $\mathrm{pH}$ from 5.5 to 6.5 and subsoils from 4.5 to 5.5 . Hydraulic conductivity varies widely.

Agriculture is livestock based; however, the province is also a major producer of seed, tablestock, and processing potatoes (Solanum tuberosum L.). 
Approximately 20000 ha of potatoes are grown annually, mostly in the upper St. John River Valley in northwestern New Brunswick. Typically a 2- to 4-yr rotation of either potatoes and cereals or potatoes, cereals, and forages (various legume and grass mixtures) is followed. Cereals and forages are grown more for their rotational value to potatoes than as cash crops. On livestock farms, cereals are often underseeded with forages, greatly limiting options for herbicide treatment. Cereals are usually consumed on-farm.

\section{Sampling procedure}

The province is divided into 15 counties. The number of fields selected for the survey was proportional to the area in cereals for each county. A stratified random sampling procedure (Cochran 1977) was used to select fields. Each of the 15 counties formed a stratum but only 13 of the counties had a cereal area large enough to be included in the survey. A total of 74 fields were surveyed during 1986 and 113 during 1987. The number of fields varied among the counties reflecting the proportional sampling: Carleton (82), Victoria (21), Restigouche (18), Kings (16), York (14), Madawaska (13), Westmoreland (8), Kent (7), Northumberland (2), Gloucester (2), Albert (2), Sunbury (1), Queens (1). Barley (Hordeum vulgare L.), oats (Avena sativa L.), and wheat (Triticum aestivum L.) were represented in the survey by 82,70 , and 35 fields, respectively. A proportion of the fields, were underseeded with a forage. For wheat, $33 \%$ of the fields were underseeded, for barley $43 \%$, and for oats $54 \%$.

A field was sampled for weeds according to an inverted W-pattern as described previously by Thomas (1985) with five quadrats, each $0.25 \mathrm{~m}^{2}$, located equidistant along each of the four arms of the pattern. The number of weeds was recorded by species in each quadrat. Shoot numbers were recorded for perennial species. A tillered annual grass was considered a single plant. In some instances, specific identification of species was not possible and similar species were grouped together by genera. Sampling was carried out between 6 July and harvest, after the application of any postemergence chemical control.

The crop rotation, crop seed source, and herbicide treatments used on both the surveyed crop and the preceding crop were obtained by interviewing the farm operator of each field. Preceding crops were classified as forage, cereal, potato, or other. The forage crop category included alfalfa (Medicago sativa L.), hay, and pasture. The other crop category (36 fields), which included numerous types of vegetables and also fields where the previous crop could not be determined, was not used in the analysis.

\section{Treatment of data}

Data for the two survey years were combined and summarized using three quantitative measures. Frequency, mean field uniformity, and mean field density were computed for each species using the method of Thomas (1985). Frequency indicates the percentage of fields infested by a species and is an estimate of geographic extent of the infestation in the province. Frequency only considers the presence or absence of the weed in a field. Mean field uniformity indicates the percentage of quadrats infested by a species and is an estimate of the area infested by a weed. Mean field density indicates the number of plants $\mathrm{m}^{-2}$ and is used to indicate the magnitude of the infestation in all the surveyed fields.

Frequency, mean field uniformity, and mean field density values for each species were combined into a single synthetic value called relative abundance as described by Thomas (1985). This value is used to rank the contribution of individual species in the weed community and to compare the contribution of groups of species. It does not indicate the competitiveness of the weed. A relative value has an advantage because it allows comparisons to be made among data collected for weed communities in various years, locations, crops, or management systems. Total value for relative abundance of all species in a community is 300 . 
The structure of weed communities for barley, oats, and wheat were explored by constructing dominance curves using relative abundance. The relative abundance values of individual species were plotted against their rank, with the species ranked in decreasing order of relative abundance. A curve with a steep declining slope indicates a weed community dominated by one or a few species whereas a curve with less slope indicates that species are more equally abundant in the community (Thomas and Ivany 1990).

To illustrate the impact on the weed community of a forage, cereal, or potato crop grown the year preceding the surveyed cereal crop, a scatter plot of relative abundance for pairs of crop rotations were prepared using only the 20 most abundant species. If the relative abundances in both rotations were similar, then the value would fall along a diagonal line indicating equal relative abundances in both rotations. Deviations greater than 10 relative abundance units from the diagonal line were considered important for purposes of discussion.

\section{RESULTS AND DISCUSSION}

\section{Weed flora}

A total of 76 species were found in quadrats during the two survey years, but 36 occurred in less than seven of the surveyed fields and were therefore considered to be of minor importance. The 40 most frequently occurring species are listed in order of their relative abundance values in Table 1. These 40 species represented 16 families and had a summed relative abundance of 289.0 out of 300 . The Asteraceae contributed 10 species and ranked first with a summed relative abundance of 60.4. The Caryophyllaceae contributed five species with a summed relative abundance of 45.8; Polygonaceae contributed three species with an abundance of 41.2; Poaceae contributed six species with an abundance of 39.1; Fabaceae contributed two species with an abundance of 17.3; and Brassicaceae contributed four species with an abundance of 6.4 Each of the remaining 10 species represented a different family: Chenopodiaceae, Equisetaceae, Lamiaceae, Oxalidaceae, Plantaginaceae, Rosaceae, Rubiaceae, Scrophulariaceae, Violaceae, Apiaceae. The importance of particular families in the weed community could not be judged solely on the basis of number of species. The Lamiaceae contributed only one of the 40 species but hemp-nettle (Galeopsis tetrahit L.) was the most abundant species in the survey.

Species with a perennial life cycle accounted for 20 of the 40 species in Table 1. Perennials were divided into two groups based on method of reproduction. Ten of the perennials spread vegetatively by means of rhizomes or roots and had a summed relative abundance of 86.7. Ten perennials were wholly dependent on seed for dispersal and their summed relative abundance was 58.2. Similar agricultural production systems in Quebec (Lemieux et al. 1988) and Prince Edward Island (Thomas and Ivany 1990) had weed floras in which perennials also accounted for approximately $50 \%$ of the species.

The 20 annual or biennial species in Table 1 had a summed relative abundance of 144.1. Only three grasses were found among the 20 annuals. The summed relative abundance of barnyard grass [Echinochloa crusgalli (L.) Beauv.], oats, and wild oats was only 4.4 and they were ranked $22^{\text {nd }}, 39^{\text {th }}$, and $40^{\text {th }}$ respectively (Table 1 ). In the neighbouring provinces of Prince Edward Island (Thomas and Ivany 1990) and Quebec (Lemieux et al. 1988), where similar crop rotations exist, it was also found that annual grasses were relatively unimportant as compared to perennial grasses such as quack grass [Agropyron repens (L.) Beauv.]. Barnyard grass, witch grass (Panicum capillare L.), crabgrass (Digitaria) species, and foxtail (Setaria) species were the most frequently encountered annual grasses in these other provinces. Wild oats was not recorded from either Prince Edward Island or Quebec. The low abundance of grassy weeds in spring cereals of New Brunswick, Prince Edward Island, and Quebec is in sharp contrast to the major contribution made 
Table 1. Species, life cycle, and quantitative measures for weed species recorded in seven or more of the fields during the 1986 and 1987 surveys of cereal crops in New Brunswick

\begin{tabular}{|c|c|c|c|c|c|c|c|}
\hline Rank & Scientific name & Common name & $\begin{array}{l}\text { Life } \\
\text { cycle }^{\mathrm{a}}\end{array}$ & $\begin{array}{l}\text { Frequency } \\
(\%)\end{array}$ & $\begin{array}{c}\text { Mean field } \\
\text { uniformity } \\
(\%)\end{array}$ & $\begin{array}{c}\text { Mean field } \\
\text { density } \\
\text { (plants } \mathrm{m}^{2} \text { ) }\end{array}$ & $\begin{array}{c}\text { Relative } \\
\text { abundance } \\
(0-300)\end{array}$ \\
\hline 1 & Galeopsis tetrahit L. & Hemp-nettle & $A$ & 74.3 & 30.9 & 7.1 & 32.8 \\
\hline 2 & $\begin{array}{l}\text { Agropyron repens (L.) Beauv. } \\
\text { [= Elytrigia repens (L.) Nevski] }\end{array}$ & Quack grass & PV & 34.8 & 14.8 & 8.0 & 23.6 \\
\hline 3 & Rumex acetosella L. & Sheep sorrel & PV & 61.5 & 19.8 & 3.7 & 21.2 \\
\hline 4 & Chrysanthemum leucanthemum $\mathrm{L}$. & Ox-eye daisy & PS & 54.0 & 20.9 & 3.7 & 20.8 \\
\hline 5 & Spergula arvensis L. & Corn spurry & A & 52.9 & 17.4 & 4.4 & 20.3 \\
\hline 6 & Stellaria media (L.) Vill. & Chickweed & $A$ & 49.7 & 15.5 & 4.2 & 19.0 \\
\hline 7 & Vicia cracca L. & Tufted vetch & PV & 49.2 & 16.7 & 2.3 & 16.0 \\
\hline 8 & Gnaphalium uliginosum $\mathrm{L}$. & Low cudweed & A & 36.4 & 8.4 & 4.3 & 14.8 \\
\hline 9 & Chenopodium album L. & Lamb's-quarters & A & 34.8 & 11.0 & 3.6 & 14.5 \\
\hline 10 & $\begin{array}{l}\text { Polygonum lapathifolium L. } \\
\text { and Polygonum persicaria L. }\end{array}$ & $\begin{array}{l}\text { Pale smartweed } \\
\text { and lady's-thumb }\end{array}$ & A & 46.5 & 10.4 & 1.2 & 11.4 \\
\hline 11 & Poa compressa L. & Canada blue grass & PV & 13.4 & 4.4 & 3.4 & 9.2 \\
\hline 12 & Polygonum convolvulus L. & Wild buckwheat & A & 34.2 & 8.3 & 0.8 & 8.6 \\
\hline 13 & Taraxacum officinale Weber & Dandelion & PS & 36.9 & 7.2 & 0.5 & 7.8 \\
\hline 14 & Oxalis stricta L. & European wood-sorrel & PS & 24.1 & 6.1 & 1.3 & 7.4 \\
\hline 15 & Plantago major $\mathrm{L}$. & Broad-leaved plantain & PS & 27.8 & 6.3 & 0.9 & 7.1 \\
\hline 16 & Potentilla spp. & Cinquefoil & PS & 24.6 & 5.7 & 1.0 & 6.7 \\
\hline 17 & $\begin{array}{l}\text { Matricaria matricarioides } \\
\text { (Less.) Porter }\end{array}$ & Pineappleweed & A & 17.6 & 2.9 & 0.4 & 3.8 \\
\hline 18 & Achillea millefolium L. & Yarrow & PV & 11.2 & 3.1 & 0.4 & 3.1 \\
\hline 19 & Cerastium fontanum Baumg. & Mouse-eared chickweed & PS & 14.4 & 2.4 & 0.3 & 3.1 \\
\hline 20 & Cirsium arvense (L.) Scop. & Canada thistle & PV & 18.7 & 1.9 & 0.1 & 3.0 \\
\hline 21 & Linaria vulgaris Mill. & Yellow toadflax & PV & 10.7 & 2.3 & 0.4 & 2.9 \\
\hline 22 & $\begin{array}{l}\text { Echinochloa crusgalli (L.) } \\
\text { Beauv. }\end{array}$ & Barnyard grass & A & 8.0 & 1.8 & 0.6 & 2.7 \\
\hline 23 & $\begin{array}{l}\text { Hieracium floribundum } \\
\text { Wimm. \& Grab. }\end{array}$ & Yellow devil hawkweed & PV & 11.8 & 1.8 & 0.2 & 2.4 \\
\hline 24 & Equisetum arvense $\mathrm{L}$. & Field horsetail & PV & 8.0 & 1.5 & 0.5 & 2.3 \\
\hline 25 & $\begin{array}{l}\text { Silene vulgaris (Moench) } \\
\text { Garcke }\end{array}$ & Bladder campion & PS & 8.0 & 2.3 & 0.3 & 2.3 \\
\hline 26 & Solidago spp. & Goldenrod & PV & 12.3 & 1.7 & 0.1 & 2.3 \\
\hline 27 & Raphanus raphanistrum L. & Wild radish & A & 11.2 & 1.5 & 0.1 & 2.1 \\
\hline 28 & $\begin{array}{l}\text { Capsella bursa-pastoris (L.) } \\
\text { Medic. }\end{array}$ & Shepherd's-purse & A & 10.2 & 1.6 & 0.1 & 1.9 \\
\hline 29 & Viola arvensis Murr. & Field violet & A & 4.8 & 1.1 & 0.6 & 1.9 \\
\hline 30 & Panicum lanuginosum Ell. & Woolly panicum & PS & 8.6 & 1.1 & 0.3 & 1.9 \\
\hline 31 & Galium mollugo L. & Smooth bedstraw & PV & 8.6 & 1.1 & 0.3 & 1.8 \\
\hline 32 & Daucus carota L. & Wild carrot & $B$ & 8.0 & 1.0 & $<0.1$ & 1.4 \\
\hline 33 & Sinapis arvensis L. & Wild mustard & $A$ & 5.9 & 1.3 & 0.1 & 1.3 \\
\hline 34 & Medicago lupulina L. & Black medick & A & 6.4 & 1.0 & 0.1 & 1.3 \\
\hline 35 & Sonchus arvensis $\mathrm{L}$. & Perennial sow-thistle & PV & 5.9 & 1.0 & 0.1 & 1.3 \\
\hline 36 & Erigeron strigosus Muhl. & Rough fleabane & $A$ & 5.9 & 0.7 & 0.1 & 1.1 \\
\hline 37 & Erysimum cheiranthoides $\mathrm{L}$. & Wormseed mustard & A & 4.8 & 1.0 & 0.1 & 1.1 \\
\hline 38 & Stellaria graminea L. & Grass-leaved stitchwort & PS & 3.7 & 0.9 & 0.2 & 1.1 \\
\hline 39 & Avena sativa $\mathrm{L}$. & Oats & $A$ & 4.8 & 0.7 & $<0.1$ & 0.9 \\
\hline 40 & Avena fatua $\mathrm{L}$. & Wild oats & A & 3.7 & 0.8 & $<0.1$ & 0.8 \\
\hline
\end{tabular}

a A: annual; B: biennial; PV: perennial species that reproduce vegetatively; PS: perennial species that only reproduce by seed. 
by grassy weeds to the weed flora in other parts of Canada. Green foxtail [Setaria viridis (L.) Beauv.] ranked first and wild oats ranked second or third in the Prairie provinces of Manitoba (Thomas 1991) and Saskatchewan (Thomas 1985) where cereal rotations are common.

Wild oats appeared in $3.7 \%$ of the New Brunswick cereal fields. This level of occurrence suggests a slight increase from the 1940s when the weed was recorded in $0.8 \%$ of sites surveyed in the Maritime region (Groh and Frankton 1949) and in 1953 when the weed was found along a roadside at one site only (Bassett 1953). Wild oats occurred primarily in fields with long cereal rotations and where nonpedigreed seed was used.

Mean field uniformity is used as an estimate of the area infested with a weed. Hemp-nettle was estimated to infest $30.9 \%$ of the area seeded to spring cereals in New Brunswick (Table 1). Sheep sorrel (Rumex acetosella L.) and ox-eye daisy (Chrysanthemum leucanthemum L.) infested approximately $20 \%$ of the area. Each of the other species infested less than $20 \%$ of the area. Wild oats only infested $0.8 \%$ of the survey area.

Several species were found infrequently in fields, but at densities greater than 5.0 plants $\mathrm{m}^{-2}$ when averaged over only the fields in which they occurred (occurrence density). Canada blue grass (Poa compressa L.), field violet (Viola arvensis Murr.), barnyard grass, field horsetail (Equisetum arvense L.), and European wood-sorrel (Oxalis stricta L.) had mean field densities of less than 3.4 plants $\mathrm{m}^{-2}$ but had occurrence densities of 25.6, 11.7, 7.8,6.1, and 5.5 plants $\mathrm{m}^{-2}$, respectively. These weeds therefore have the potential to be a problem if they spread into previously uninfested fields.

Most of the species listed in Table 1 were recognized as weeds of fields and waste areas nearly $100 \mathrm{yr}$ ago (Fletcher 1897). Little change in the species composition of the weed flora had occurred when Bassett (1953) prepared his list 50 $\mathrm{yr}$ later. Four species found among the
40 most abundant weeds in the current surveys of New Brunswick were absent from these previous lists. Canada blue grass, European wood-sorrel, field violet, and woolly panicum (Paricum lanuginosum Ell.) are species that may have increased in abundance and populations of these species should be monitored in the future.

Of the 76 species found in the survey, 36 occurred in less than $3.5 \%$ of the fields and contributed a summed relative abundance of only 11.0 (Table 2). Although rarely encountered in the surveyed fields, some of these species may become more important members of future weed communities if changes occur in crop management practices. Field mint (Mentha arvensis L.), y'ellow nut sedge (Cyperus esculentus L.), common milkweed (Asclepias syriaca L.), common mallow (Malva neglecta Wallr.), and colt's-foot (Tussilago farfara L.) were absent or rare in previous surveys (Bassett 1953) and are generally considered by extension staff to be on the increase in the province and their abundance should be closely monitored.

\section{Herbicide use and species abundance}

MCPA [(4-chloro-2-methylphenoxy)acetic acid] was the most commonly used herbicide on surveyed spring cereals. It was applied either alone or as part of a $\mathrm{mix}$ to $68 \%$ of the fields. $2,4-\mathrm{D}[(2,4-$ dichlorophenoxy)acetic acid] or 2,4-DB [4-(2,4-dichlorophenoxy)butanoic; acid] were applied either alone or as part of a mix to $18 \%$ of the fields. Only $5 \%$ of the fields received a herbicide other than these three. More than one herbicide was applied to $10 \%$ of the fields and $19 \%$ of all the fields did not receive a herbicide. The percentage of treated fields was lowest for oats at $67 \%$, intermediate for barley at $89 \%$, and highest for wheat where all the fields were treated. Survey results indicate that oats and barley planted following forages were treated less than when planted following cereals or potatoes. The number of wheat fields following a forage (two fields) or cereal crop (five fields) was too few to give an adequate indication of herbicide use and species abundance. 
Table 2. Frequency of species occurring in less than $3.5 \%$ of the cereal fields surveyed in New Brunswick

\begin{tabular}{|c|c|c|}
\hline Scientific name & Common name & $\begin{array}{c}\text { Frequency } \\
(\%)\end{array}$ \\
\hline Ranunculus acris L. & Tall buttercup & 3.2 \\
\hline Solanum tuberosum L. & Potato & 3.2 \\
\hline Setaria glauca (L.) Beauv. & Yellow foxtail & 2.7 \\
\hline Mentha arvensis $\mathrm{L}$. & Field mint & 2.7 \\
\hline Medicago sativa $\mathrm{L}$. & Alfalfa & 2.1 \\
\hline Hordeum vulgare $\mathrm{L}$. & Barley & 2.1 \\
\hline Amaranthus retroflexus $\mathrm{L}$. & Redroot pigweed & 2.1 \\
\hline Carex spp. & Sedges & 2.1 \\
\hline Fragaria virginiana Duchesne & Strawberry & 2.1 \\
\hline Fagopyrum esculentum Moench & Buckwheat & 1.6 \\
\hline Polygonum hydropiper L. & Marshpepper smartweed & 1.6 \\
\hline Setaria viridis (L.) Beauv. & Green foxtail & 1.6 \\
\hline Polygonum ramosissimum Michx. & Yellow-flowered knotweed & 1.6 \\
\hline Polygonum aviculare L. & Prostrate knotweed & 1.6 \\
\hline Poa pratensis $\mathrm{L}$. & Kentucky blue grass & 1.1 \\
\hline Cyperus esculentus L. & Yellow nut sedge & 1.1 \\
\hline Leontodon autumnalis $\mathrm{L}$. & Fall hawkbit & 1.1 \\
\hline Asclepias syriaca $\mathrm{L}$. & Common milkweed & 1.1 \\
\hline Polygonum cuspidatum Sieb. \& Zucc. & Japanese knotweed & 1.1 \\
\hline Sedum telephium L. & Live-forever stonecrop & 1.1 \\
\hline Spiraea latifolia (Ait.) Borkh. & Broad-leaved meadowsweet & 1.1 \\
\hline Malva neglecta Wallr. & Common mallow & 1.1 \\
\hline Senecio vulgaris $\mathrm{L}$. & Common groundsel & 0.5 \\
\hline Sonchus oleraceus L. & Annual sow-thistle & 0.5 \\
\hline Ambrosia artemisiifolia L. & Common ragweed & 0.5 \\
\hline Rubus spp. & Raspberry & 0.5 \\
\hline Brassica campestris L. & Bird rape & 0.5 \\
\hline Apocynum androsaemifolium L. & Spreading dogbane & 0.5 \\
\hline Lysimachia terrestris (L.) BSP. & Swamp loosestrife & 0.5 \\
\hline Agrostis capillaris L. & Colonial bent grass & 0.5 \\
\hline Eupatorium maculatum L. & Spotted Joe-Pye weed & 0.5 \\
\hline Tussilago farfara L. & Colt's-foot & 0.5 \\
\hline Epilobium angustifolium $\mathrm{L}$. & Fireweed & 0.5 \\
\hline Aster simplex Willd. & Tall white aster & 0.5 \\
\hline Veronica officinalis L. & Common speedwell & 0.5 \\
\hline
\end{tabular}

Herbicide treatment applied to the field in the year preceding the survey was strongly correlated with the type of crop grown. No herbicides were used on any of the forage crops. The proportion of cereals grown the preceding year that received a herbicide treatment of MCPA, 2,4-D, dicamba (3,6-dichloro-2methoxybenzoic acid), or bromoxynil (3,5-dibromo-4-hydroxybenzonitrile) was $67 \%$, and $84 \%$ of potatoes grown the preceding year received metribuzin [4-amino-6-(1,1-dimethylethyl)-3(methylthio)-1,2,4-triazin-5(4H)-one], dinoseb [2-(1-methylpropyl)-4,6-dinitro- phenol], or one of several other herbicide treatments.

Hemp-nettle was the most widespread species in New Brunswick cereal crops infesting $74.3 \%$ of surveyed fields with a mean field uniformity of $30.9 \%$ and a mean density of 7.1 plants $\mathrm{m}^{-2}$ (Table 1). Improper herbicide selection and time of application are important reasons for the first place ranking of hemp-nettle. Generally hemp-nettle control from MCPA is poor, but some control is possible if applications are made before the 4-leaf stage and high 
rates are applied. Hemp-nettle is not susceptible to $2,4-D$ or $2,4-D B$. A lack of control throughout most of the crop rotation would ensure adequate seed supplies for maintaining high population levels. Hemp-nettle is capable of producing enough seeds to reinfest a field, even when growing in a highly competitive crop such as oats (Légère and Deschênes 1989).

The data clearly indicate that herbicides used by New Brunswick farmers were not effective against the seven most abundant weeds and many of the other species in Table 1. The perennial weeds, quack grass, sheep sorrel, ox-eye daisy, and tufted vetch (Vicia cracca L.) were ranked $2^{\text {nd }}, 3^{\text {rd }}$, $4^{\text {th }}$, and $7^{\text {th }}$, respectively. These species would not be adequately controlled by the herbicides used on spring cereals (Ontario Ministry of Agriculture and Food 1988). Two of the Caryophyllaceae, corn spurry (Spergula arvensis L.) and chickweed [Stellaria media (L.) Vill.], which are not controlled by MCPA and 2,4-D, were ranked $5^{\text {th }}$ and $6^{\text {th }}$. Farmers can make major improvements in cereal weed control by choosing a herbicide that will control species tolerant to MCPA or 2,4-D.

Species that are known to be susceptible to MCPA and 2,4-D were also found in a number of fields. Lamb's-quarters (Chenopodium album L.) was found in $35 \%$ of the fields at densities of 3.6 plants $\mathrm{m}^{-2}$ and low cudweed (Gnaphalium uliginosum L.) was found in $36 \%$ of the fields and at densities of 4.3 plants $\mathrm{m}^{-2}$ even though MCPA and 2,4-D should have adequately controlled these weeds. Individuals of these species may have emerged subsequent to herbicide application because of intermittent germination. Hume (1988) lists nine other mechanisms that would allow plants to avoid or escape the effects of herbicides. Detailed field monitoring would be required to fully understand the incidence of lamb's-quarters.

\section{Crop rotation and species abundance}

Seven types of rotations were found in the surveyed fields (Table 3 ). For example, $53 \%$ of the barley fields followed potatoes and $23 \%$ followed a forage crop. In contrast, $30 \%$ of the oat: fields followed potatoes and $48 \%$ followed forage crops. Herbicide use patterns, total weed density, and relative abundance were related to these rotations. Extensive use of herbicides in some rotations would have selectively removed some sensitive species creating space for other species to expand their populations. This type of response was least important in oats following forages because only $45 \%$ of the fields received a herbicide treatment in the survey year (Table 3 ) and no herbicides the previous year. Tufted vetch, ox-eye daisy, and sheep sorrel are perennials and were the highest ranked species in this rotation. The weed community in wheat following potatoes was associated with a more intensive use of herbicides $(100 \%$ of the fields treated). This may explain the prevalence of two Caryophyllaceae, chickweed and corn spurry, not controlled by the herbicides used on wheat. These two species are most abundant following potatoes, less abundant following cereals, and do not occur among the first three species following forages. A similar change in the quantitative aspects of community structure was documented for the longterm effects of 2,4-D on the weed community in wheat (Hume 1987).

Quack grass was prevalent in oats or barley when forage or cereal crops were grown the previous year but did not rank in the first three species in fields after potatoes (Table 3). High herbicide use, extensive cultivation, and vine desiccation and soil disturbance associated with fall harvest in potatoes would make it difficult for perennials to survive. Quack grass would be expected to be prevalent when cereal crops were grown the preceding year because farmers allow quack grass to grow in oat and barley fields for a month or more after harvest. Perennial weed infestations resulting from preceding forage crops and cereals could be minimized by better preplant weed control and postharvest weed control, respectively.

A further indication of the relationship between the crop grown the year preceding the survey and the relative 
Table 3. Characteristics of weed communities found in oats, barley, and wheat when perennial, cereal, or potato crops were grown previously

\begin{tabular}{|c|c|c|c|c|c|c|}
\hline $\begin{array}{l}\text { Previous } \\
\text { crop type }\end{array}$ & Crop & $\begin{array}{l}\text { Number of } \\
\text { fields }\end{array}$ & $\begin{array}{c}\text { Fields treated } \\
\text { with herbicides } \\
(\%)\end{array}$ & $\begin{array}{c}\text { Total weed } \\
\text { density } \\
\text { (plants } \mathrm{m}^{-2} \text { ) }\end{array}$ & $\begin{array}{c}\text { Three most abundant } \\
\text { species in } \\
\text { surveyed crop }\end{array}$ & $\begin{array}{l}\text { Cumulative relative } \\
\text { abundance of } \\
\text { first three species }\end{array}$ \\
\hline \multirow[t]{6}{*}{ Forage } & oats & 29 & 45 & 103 & tufted vetch & 26.5 \\
\hline & & & & & ox-eye daisy & 52.0 \\
\hline & & & & & sheep sorrel & 75.3 \\
\hline & barley & 16 & 69 & 73 & hemp-nettle & 38.4 \\
\hline & & & & & quack grass & 75.3 \\
\hline & & & & & lamb's-quarters & 99.7 \\
\hline \multirow[t]{6}{*}{ Cereal } & oats & 14 & 86 & 65 & hemp-nettle & 44.4 \\
\hline & & & & & quack grass & 87.8 \\
\hline & & & & & corn spurry & 114.6 \\
\hline & barley & 17 & 88 & 75 & hemp-nettle & 49.9 \\
\hline & & & & & chickweed & 93.0 \\
\hline & & & & & quack grass & 128.4 \\
\hline \multirow[t]{8}{*}{ Potato } & oats & 18 & 89 & 31 & hemp-nettle & 36.6 \\
\hline & & & & & corn spurry & 68.8 \\
\hline & & & & & Canada blue grass & 98.4 \\
\hline & barley & 37 & 97 & 26 & $\begin{array}{l}\text { chickweed } \\
\text { hemp-nettle }\end{array}$ & $\begin{array}{l}46.7 \\
82.5\end{array}$ \\
\hline & & & & & corn spurry & 111.2 \\
\hline & wheat & 20 & 100 & 24 & chickweed & 47.3 \\
\hline & & & & & corn spurry & 92.8 \\
\hline & & & & & low cudweed & 128.9 \\
\hline
\end{tabular}

a Based on a total maximum of 300 .

abundance of specific weeds is shown in Figure 1. Rotations involving forage crops allow for establishment, growth, and reproduction of perennial species that persist in subsequent cereal crops. The relative abundance of quack grass and hemp-nettle in the surveyed crops were higher in fields with cereals grown previously than in fields with forage or potato crops grown previously. Low cudweed and Canada blue grass had a higher relative abundance in the surveyed crops when potatoes were grown previously than in cereals grown previously.

\section{Community structure}

The response of the weed community to different herbicide use patterns and crop rotations is summarized by the dominance curves for barley, oats, and wheat (Fig. 2). Dominance curves indicate that the most diverse weed communities are found in oats following forages and the least diverse in wheat following potatoes and barley follow- ing cereals. Differences in the shape of the dominance curves is indicated by the cumulative relative abundance of the first three species (Table 3 ). The weed community in oats following forage crops had the smallest cumulative abundance (75.3) for the first three species. The dominance curve for oats after forage crops is most similar in shape to the curve for cereals on Prince Edward Island (Thomas and Ivany 1990). In both provinces, weed communities are influenced by a lack of or limited use of herbicides, partly because many fields are underseeded to a legume. The weed community in surveyed crops following potatoes or cereals is more strongly dominated by the first three species than is the weed community following forages. The curve for wheat after potatoes resembles the dominance curve for Saskatchewan cereal and oilseed crops (Thomas 1985). In Saskatchewan herbicides are used extensively and the first three ranked species had a relative abundance of 132.3 . 


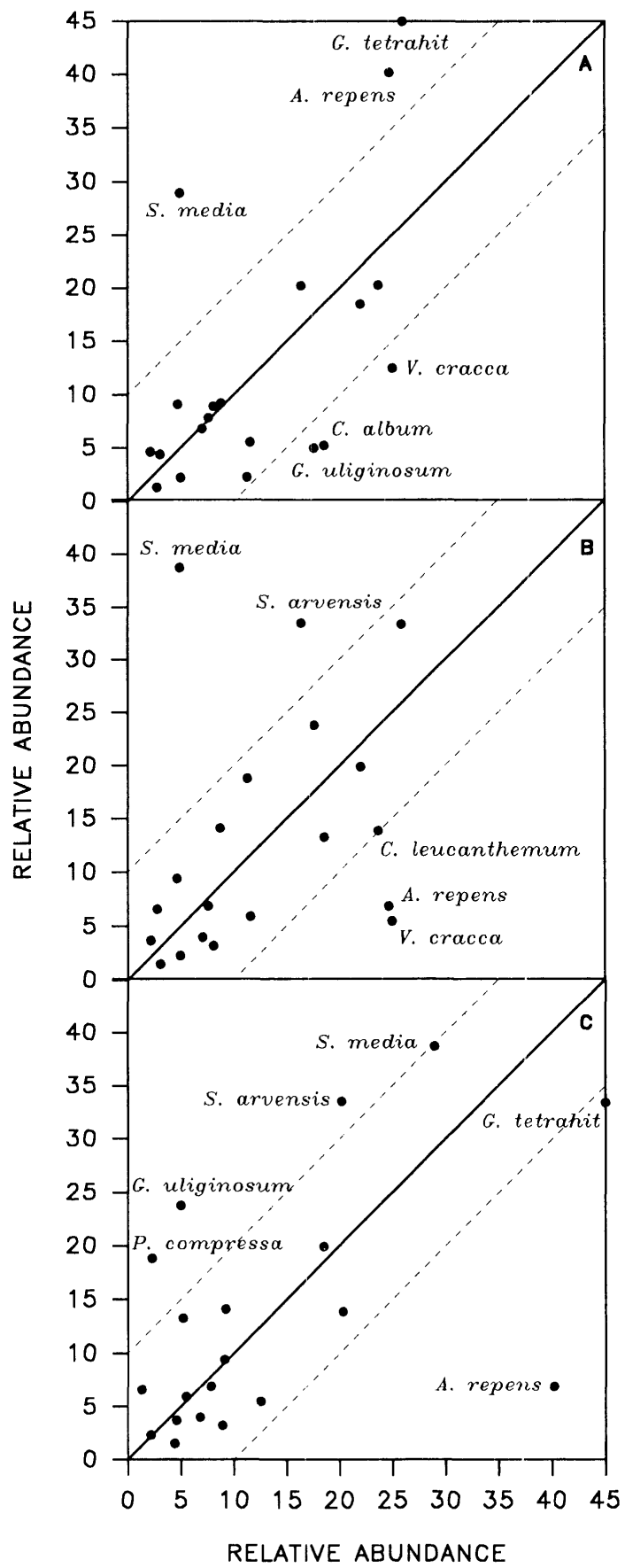

Figure 1. Comparison of the relative abundance (RA) of the $\mathbf{2 0}$ most abundant species in the surveyed cereal fields. A) RA when forages ( $x$-axis) or cereals ( $y$-axis) were grown previously; B) RA when forages $(x)$ or potatoes $(y)$ were grown previously; C) RA when cereals $(x)$ or potatoes $(y)$ were grown previously. Species falling between the dashed lines were considered equally abundant $( \pm 10)$ in both rotations. 


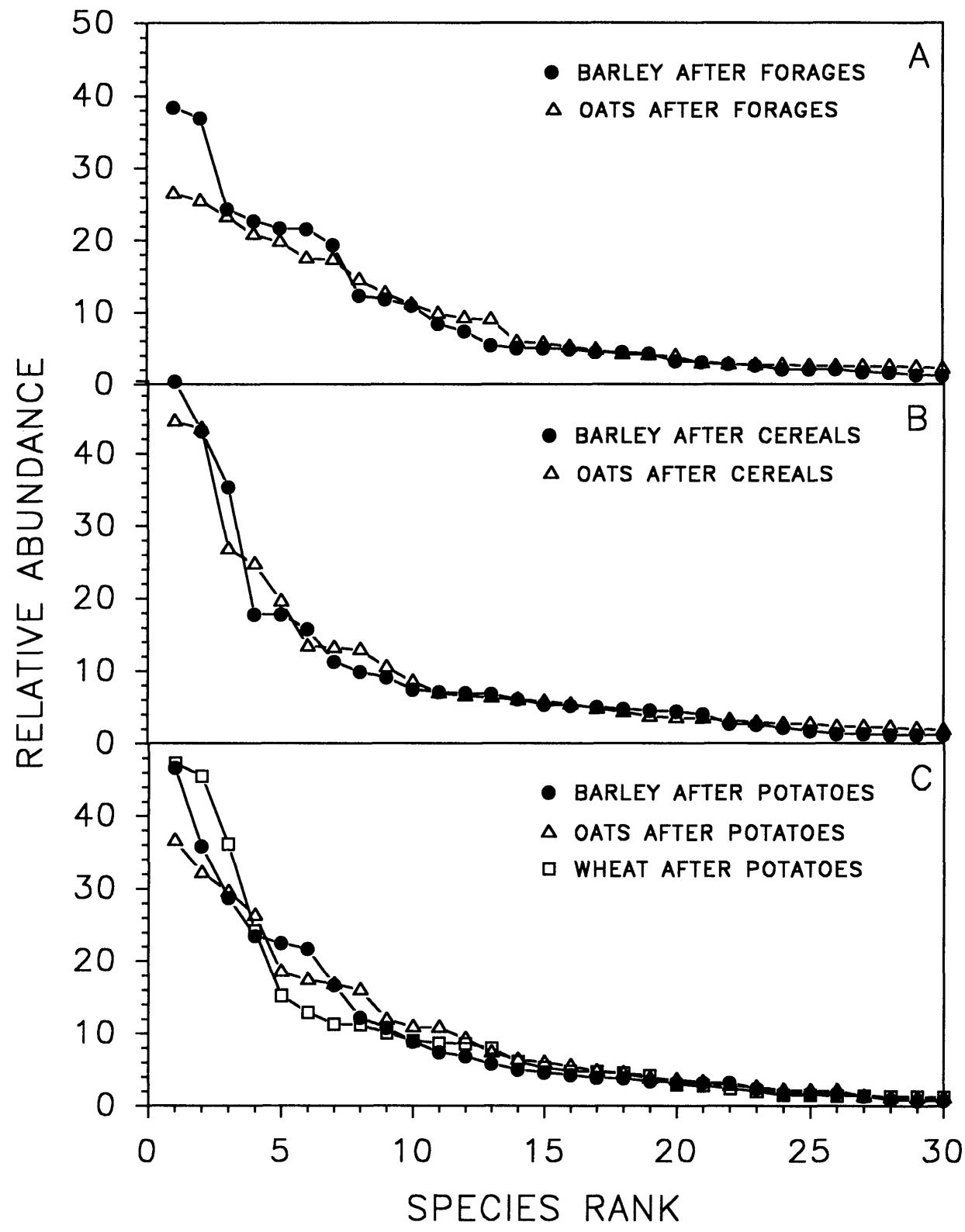

Figure 2. Dominance curves of the $\mathbf{3 0}$ most abundant species in barley, oats, and wheat in New Brunswick following A) forages, B) cereals, and C) potatoes. Species are plotted in descending order based on relative abundance. 


\section{ACKNOWLEDGEMENTS}

This research was funded by the New Brunswick AgriFood Development Agreement. The technical assistance of Larry Gregan, Susan Bower, and Robin Wise is gratefully acknowledged.

\section{REFERENCES}

Bassett, I.J. 1953. A weed survey in New Brunswick - 1953. Pages 66-81 in Proc. Seventh Meeting, Eastern Section, National Weed Committee, Ottawa, Canada.

Cochran, W.G. 1977. Sampling techniques, $3^{\text {rd }}$ ed. John Wiley \& Sons, New York. $428 \mathrm{pp}$.

Dale, M.R.T., and A.G. Thomas. 1987. The structure of weed communities in Saskatchewan fields. Weed Sci. 35: 348-355.

Doyon, D., and C.J. Bouchard. 1981. A survey of weeds found in fields of graincorn in St-Hyacinthe county, Quebec (In French). Phytoprotection 62: 1-10.

Doyon, D., J.-M. Deschênes, C.J. Bouchard, and R. Rioux. 1982. Les inventaires de mauvaises herbes dans les principales cultures au Québec. 1. Buts et méthodologie. Phytoprotection 63: 10-21.

Fletcher, J. 1897. Weeds. Dep. Agric. Bull. 28, Ottawa, Canada. 43 pp.

Goodwin, M.S., I.N. Morrison, and A.G. Thomas. 1986. A weed survey of pedigreed alfalfa seed fields in Manitoba. Can. J. Plant Sci. 66: 413-416.

Groh, H., and C. Frankton. 1949. Canadian weed survey. Seventh Report. Canada Dep. Agric., Ottawa, Canada. 144 pp.

Hume, L. 1987. Long-term effects of 2,4-D applications on plants. I. Effects on the weed community in a wheat field. Can. J. Bot. 65: 2530-2536.

Hume, L. 1988. Long-term effects of 2,4-D applications on plants. II. Herbicide avoidance by Chenopodium album and Thlaspi arvense. Can. J. Bot. 66: 230-235.
Légère, A., and J.-M. Deschênes. 1989. Effects of time of emergence, population density and interspecific competition on hemp-nettle (Galeopsis tetrahit) seed production. Can. J. Plant Sci. 69: 185-194.

Lemieux, C., A. Larouche, A. Légère, J.-M. Deschênes, and R. Rioux. 1988. Inventaires des mauvaises herbes au Québec; cultures céréalières. Agric. Can. Res. Sta. Ext. Bull. 2, Sainte-Foy, Québec. $84 \mathrm{pp}$.

McCully, K.V., M.G. Sampson, and A.K. Watson. 1991. Weed survey of Nova Scotia lowbush blueberry (Vaccinium angustifolium) fields. Weed Sci. 39: 180185.

Ontario Ministry of Agriculture and Food. 1988. Guide to weed control. Publication 75, Agdex 641, Queens Printer for Ontario, Toronto, Ontario. 200 pp.

Sharma, M.P., and W.H. Vanden Born. 1978. The biology of Canadian weeds. 27. Avena fatua L. Can. J. Plant Sci. 58: 141157.

Thomas, A.G. 1985. Weed survey system used in Saskatchewan for cereal and oilseed crops. Weed Sci. 33: 34-43.

Thomas, A.G. 1991. Floristic composition and relative abundance of weeds in annual crops of Manitoba. Can. J. Plant Sci. 71: 831-839.

Thomas, A.G., and M.R.T. Dale. 1991. Weed community structure in spring seeded crops in Manitoba. Can J. Plant Sci. 71: 1069-1080.

Thomas, A.G., and D.I. Donaghy. 1991. A survey of the occurrence of seedling weeds in spring annual crops in Manitoba. Can. J. Plant Sci. 71: 811-820.

Thomas, A.G., and J.A. Ivany. 1990. The weed flora of Prince Edward Island cereal fields. Weed Sci. 38: 119-124.

Van Groenewoud, H. 1984. The climatic regions of New Brunswick: a multivariate analysis of meteorological data. Can. J. For. Res. 14: 389-394. 